EGG-GTH--5521

DE82 008328

\title{
PRELIMINARY GEOTHERMAL OISPOSAL CONSIDERATIONS, STATE HEALTH LABORATORY, BOISE, IDAHO
}

I. A. Engen

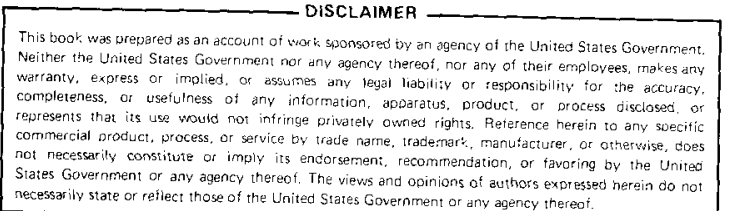

Published February 1982

EG\&G Idaho, Inc. Idaho Falls, Idaho 83415

Prepared for the

U.S. Department of Energy Idaho Operations Office

Under DOE Contract No. DE-ACO7-76ID01570 


\section{DISCLAIMER}

This report was prepared as an account of work sponsored by an agency of the United States Government. Neither the United States Government nor any agency Thereof, nor any of their employees, makes any warranty, express or implied, or assumes any legal liability or responsibility for the accuracy, completeness, or usefulness of any information, apparatus, product, or process disclosed, or represents that its use would not infringe privately owned rights. Reference herein to any specific commercial product, process, or service by trade name, trademark, manufacturer, or otherwise does not necessarily constitute or imply its endorsement, recommendation, or favoring by the United States Government or any agency thereof. The views and opinions of authors expressed herein do not necessarily state or reflect those of the United States Government or any agency thereof. 


\section{DISCLAIMER}

Portions of this document may be illegible in electronic image products. Images are produced from the best available original document. 


\section{ABSTRACT}

The State of Idaho has converted its public Health and Agriculture Laboratory Building to geothermal space heating to take advantage of the opportunity for lower assessment and the resulting economic benefit. This report presents preliminary considerations regarding geothermal effluent disposal. It was concluded that disposal of the effluent to the Boise River or to an irrigation canal would require a mechanism such as a spray cooling pond to cool the effluent prior to discharge. 


\section{FOREWORD}

The Geothermal Technical Assistance Program was developed under the premise that the majority of groups or individuals with available geothermal resources do not have the experience or manpower necessary to do a preliminary engineering and economic feasibility evaluation for geothermal energy projects. In order to disseminate technical information and to facilitate expanded use of geothermal energy resources, assistance was provided through FY-1981 in a consulting format on a first-come, staff-and-funds-available basis. Technical assistance can relate to conceptualization; engineering; economics; water chemistry implications for environmental, disposal, and material selection considerations; and planning and development strategies. This report is one of a series adapted from consultation provided to requesters either through in-house efforts or, through 1 imited efforts subcontracted to local engineering firms. The Geothermal Technical Assistance (GTA), reports in this series, which are listed below, will be available early in 1982 to those with interest in specific geothermal applications.

\begin{tabular}{|c|c|c|}
\hline $\begin{array}{c}\text { GTA } \\
\text { Report No. }\end{array}$ & $\begin{array}{c}\text { EG\&G } \\
\text { Report No. }\end{array}$ & Title \\
\hline 1. & EGG-GTH-5512 & $\begin{array}{l}\text { Aquaculture Facility Potential at Boulder Hot } \\
\text { Springs, Boulder, Montana }\end{array}$ \\
\hline 2. & EGG-GTH-5521 & $\begin{array}{l}\text { Prel iminary Geothermal Disposal Considerations, } \\
\text { State Health Laboratory, Boise, Idaho }\end{array}$ \\
\hline 3. & $E G G-G T H-5573$ & $\begin{array}{l}\text { Geothermal Conversion at Veterans Hospital, } \\
\text { Boise, Idaho }\end{array}$ \\
\hline 4. & EGG-GTH-5574 & Geothermal Applications for Highway Rest Areas \\
\hline 5. & EGG-GTH-5575 & Geothermal Applications for a Tannery \\
\hline 6. & EGG-GTH-5599 & $\begin{array}{l}\text { Preliminary Conceptual Design for Geothermal } \\
\text { Space Heating Conversion of School District } 50 \\
\text { Joint Facilities at Pagosa Springs, Colorado }\end{array}$ \\
\hline 7. & $E G G-G T H-5617$ & $\begin{array}{l}\text { Selected Geothermal Technical Assistance Efforts } \\
\text { (comprising short descriptions of ten space } \\
\text { heating projects, five district heating pro- } \\
\text { jects, and three heat exchanger projects) }\end{array}$ \\
\hline
\end{tabular}


GTA EG\&G

Report No. Report No.

Tit le

\begin{tabular}{|c|c|c|}
\hline 8. & EGG-2137 & $\begin{array}{l}\text { Geothermal Source Potential and Utilization for } \\
\frac{\text { Methane Generation and Alcohol Production }}{\text { (subcontractor report) }}\end{array}$ \\
\hline 9 & $E G G-2138$ & $\begin{array}{l}\text { Geothermal Source Potential and Utilization for } \\
\text { Alcohol Production (subcontractor report) }\end{array}$ \\
\hline & $E G G-2139$ & $\begin{array}{l}\text { Potential Geothermal Energy App lications for } \\
\frac{\text { Idaho Elks Rehabilitation Hospital }}{\text { (subcontractor report) }}\end{array}$ \\
\hline & $E G G-2144$ & $\begin{array}{l}\text { Technical Assistance Report on a Geothermal } \\
\text { Heating Utility for Lemmon, South Dakota } \\
\text { (subcontractor report) }\end{array}$ \\
\hline
\end{tabular}

12. EGG-2145

Economic Analysis for Utilization of Geothermal Energy by North Dakota Concrete Products Company (subcontractor report)

13. $E G G-2146$

Geothermal Feasibility Analysis II for Polo

School District No. 29-2, South Dakota

(subcontractor report)

14. $E G G-2147$

Preliminary Feasibility Study of Heating and Cooling ATternatives for Nebraska Western College, Scottsbluff, Nebraska (contractor report)

15. $\quad E G G-2148$

Inventory of Thermal Springs and Wells Within a One-Mile Radius of Yucca Lodge, Truth or Consequences, New Mexico (subcontractor report)

16. $E G G-2149$

Space Heating for Spa Facilities at 0 jo Caliente, New Mexico (subcontractor report)

17. $\quad E G G-2150$

Geothermal Heated Office Building at Glenwood Springs, Colorado (subcontractor report)

18. $\quad E G G-2151$

Final Report--Dickinson Geothermal Study, Dickinson, North Dakota (subcontractor report)

19. $E G G=2152$

CANCELLEDO

20. $\mathrm{EGG}-2153$

Comparison of Two Options for Supplying Geothermal Energy to the Veterans Administration Medical Center at MarTin, Texas (subcontractor report) 
GTA

Report No. Report No.

21.

$E G G-2154$

22. $E G G-2155$

23. $E G G-2156$

24.

25.

26.

27.

$E G \& G$
Title

Geothermal Utilization at Castle Oaks Subdivision, Castle Rock, Colorado (subcontractor report)

Space Heating for Twin Lakes School Near Gallup, New Mexico (subcontractor report)

Pumping Tests of Well Campbell Et AT. No. 2, GiTa Hot Springs, Grant County New Mexico (subcontractor report)

EGG-GTH-5739 Geothermal Deicing of Highways and Bridge Structures

EGG-GTH-5740 Assessment of a Geothermal Application at Tuscon, Arizona

EGG-GTH-5741 Heat Pump Systems for Spring Creek, Montana

EGG-GTH-5779 Pipe Selection Guide 


\section{CONTENTS}

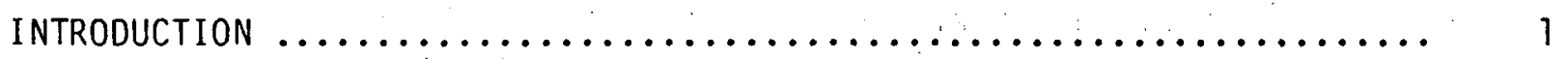

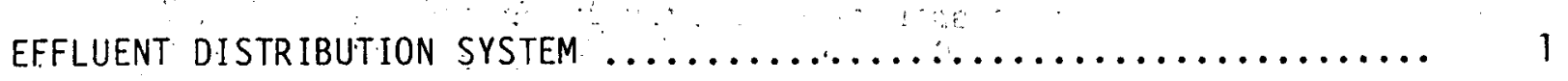

EFFLUENT TEMPERATURE $\ldots \ldots \ldots \ldots \ldots \ldots \ldots \ldots \ldots \ldots \ldots \ldots \ldots \ldots \ldots \ldots \ldots$

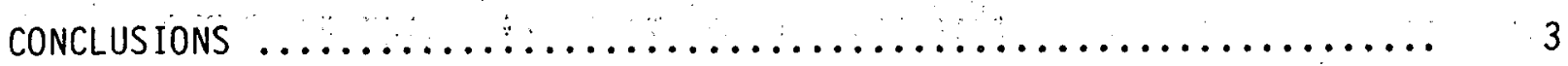

FIGURES

1. Geothermal effluent disposal options $\ldots \ldots \ldots \ldots \ldots \ldots \ldots \ldots \ldots \ldots$

2. Cooling of effluent over distance, with and without spray

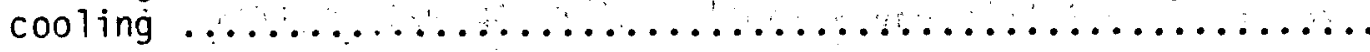

TABLE

1. Estimated Effluent Temperatures (Effluent--240 gpm summer, $400 \mathrm{gpm}$ winter, $\mathrm{T}=134^{\circ} \mathrm{F}$ ) 
PRELIMINARY GEOTHERMAL DISPOSAL CONSIDERATIONS,

STATE HEALTH LABORATORY, BOISE, IDAHO

\section{INTRODUCTION}

The State of Idaho has converted its Public Health and Agriculture Laboratory Building to geothermal space heating to take advantage of the opportunity for lower assessment and the resulting economic benefit. This conversion was an initial step in the conversion of a number of public buildings in Boise, Idaho in order to reduce or eliminate the demand for fossil fuel heating of those buildings. Development of an adequate means for disposing of geothermal water after heat extraction was probably the most important part of this first conversion effort. Disposal methods that seemed feasible included evaporation and leach ponds, reinjection, discharge to the Boise River, and the reuse of this geothermal water, at least in part, for irrigation. The information that follows is the result of preliminary work done to assess the feasibility of discharge to the Boise River.

\section{EFFLUENT DISTRIBUTION SYSTEM}

The State Health Building is located about $1 / 2 \mathrm{mile}$ northeast of the Boise River. The abandoned Cruzen-Perrant Canal and the presently used City Canal, which pass near the building site, were considered for inclusion in an effluent disposal system. Using the abandoned canal would require regarding and conditioning to obtain a head loss of 2 to 4 feet over a distance of about 5600 feet between the point of discharge into the canal and a final point of discharge from the canal to the river." A means for crossing the City Canal and the excavation of about 200 feet of new channel would also be required to intersect the river downstream from the diversion dam. As an al ternative" approach, "eff luent. could be discharged to the abandoned canal and then to the City Canal after traversing only about 800 feet of regraded canal. The effluent would then flow approximately two miles to the Boise River. During the irrigation, season, this effluent could be mixed with a much larger volume of irrigation water and distributed to irrigable lands. Available information was not clear enough to determine how the City Canal flow was distributed. At a division of the canal near the Boise City 
1 imits, one channel apparently returns to the river below the Broadway Street Bridge after confluence with the Freestone-Cottonwood Creek flow. A better understanding of how this canal water is distributed and used was required before proceeding with final discharge plans.

The importance of establishing a disposal means applicable to a larger expanded project might lead to more than one initial disposal selection and perhaps a choice of both alternative effluent flow paths.

\section{EFFLUENT TEMPERATURE}

The geothermal effluent was assumed to be discharged to the disposal system at a maximum of $400 \mathrm{gpm}$ with a temperature of $134^{\circ} \mathrm{F}$. This maximum flow would be for a winter design degree day.

Based on the need for precise temperature and humidity control in the laboratory, air reheat energy requirements during summer months were assumed to be $60 \%$ of the winter time heating requirements. Therefore, an effluent flow of $240 \mathrm{gpm}$ at $134^{\circ} \mathrm{F}$ could be expected during summer conditions.

The temperature of the effluent in the disposal system was an important consideration because of environmental effects and possible danger to the public.

Direct discharge of $134^{\circ} \mathrm{F}$ water to an abandoned canal would require extensive fencing to protect the public. The temperature would only drop to about $85^{\circ} \mathrm{F}$ at discharge to the Boise River under ordinary atmospheric conditions, assuming a flow rate of $240 \mathrm{gpm}$. This temperature is an estimate based on evaporative heat loss from a surface area of $24,000 \mathrm{ft}^{2}$ under summer conditions. Solar radiant heating and heat loss to the earth are negligible in comparison to the evaporative heat loss. Under winter conditions, the discharge flow would be cooled to about $65^{\circ} \mathrm{F}$ at the river discharge point. Thus, effluent cooling prior to canal discharge appeared necessary. Discharge to the City Canal. would be at about $127^{\circ} \mathrm{F}$ if that option were selected for summer irrigation flow disposal. 
A spray cooling pond with a surface area of about $930 \mathrm{ft}^{2}$ could be used to reduce effluent temperature from $134^{\circ} \mathrm{F}$ to the summer design dry bulb temperature of $95^{\circ} \mathrm{F}$. Assuming an average heat dissipation rate of $127 \mathrm{Btu} /$ $\mathrm{hr} / \mathrm{ft}^{2}{ }^{\circ} \mathrm{F}$ and ordinary summer atmospheric conditions, the implied efficiency of the spray pond would be $56.5 \%$ where efficiency, e, is defined as:

$\mathrm{e}=$ effluent $\Delta \mathrm{T} /$ (initial water temp - wet bulb temp) $\times 100$. Assumed wet buib temperature is $65^{\circ} \mathrm{F}$.

The required size for a 50\% efficient spray pond would be $1052 \mathrm{ft}^{2}$; size and shape of the spray pond would be affected by prevailing wind and nozzle design.

Discharge to the abandoned canal at $95^{\circ} \mathrm{F}$ would result in a temperature of about $74^{\circ} \mathrm{F}$ (or ambient temperature, depending on conditions) at discharge to the Boise River. Bischarge temperature to the City Canal would be at about $92^{\circ} \mathrm{F}$ if the previously described option were selected. The foregoing discussion may be clarified by referring to Table 1 and Figures 1 and 2 .

TABLE 1. ESTIMATED EFFLUENT TEMPERATURES (Effluent--240 gpm summer, $400 \mathrm{gpm}$ winter, $\mathrm{T}=134^{\circ} \mathrm{F}$ )

\begin{tabular}{|c|c|c|c|c|}
\hline Conditions & $\begin{array}{c}\text { Discharge to } \\
\text { Spray Pond } \\
\left({ }^{\circ} \mathrm{F}\right)\end{array}$ & $\begin{array}{c}\text { Discharge to } \\
\text { Canal } \\
(\circ \mathrm{F}) \\
\end{array}$ & $\begin{array}{c}\text { Discharge to } \\
\text { City Canal } \\
\text { (if used) } \\
\left({ }^{\circ} \mathrm{F}\right) \\
\end{array}$ & $\begin{array}{c}\text { Discharge to } \\
\text { Boise River } \\
(\mathrm{O})\end{array}$ \\
\hline Summer--no spray pond: & -- & 134 & 127 & 85 \\
\hline Summer--with spray pond: & 134 & 95 & 92 & 74 or ambient \\
\hline Winter--no spray pond & -- & 134 & 123 & 65 \\
\hline
\end{tabular}

\section{CONCLUSIONS}

Disposal of the geothermal effluent by discharge to the Boise River or to an irrigation canal would require a mechanism such as a spray cooling pond to cool the effluent prior to canal discharge. 


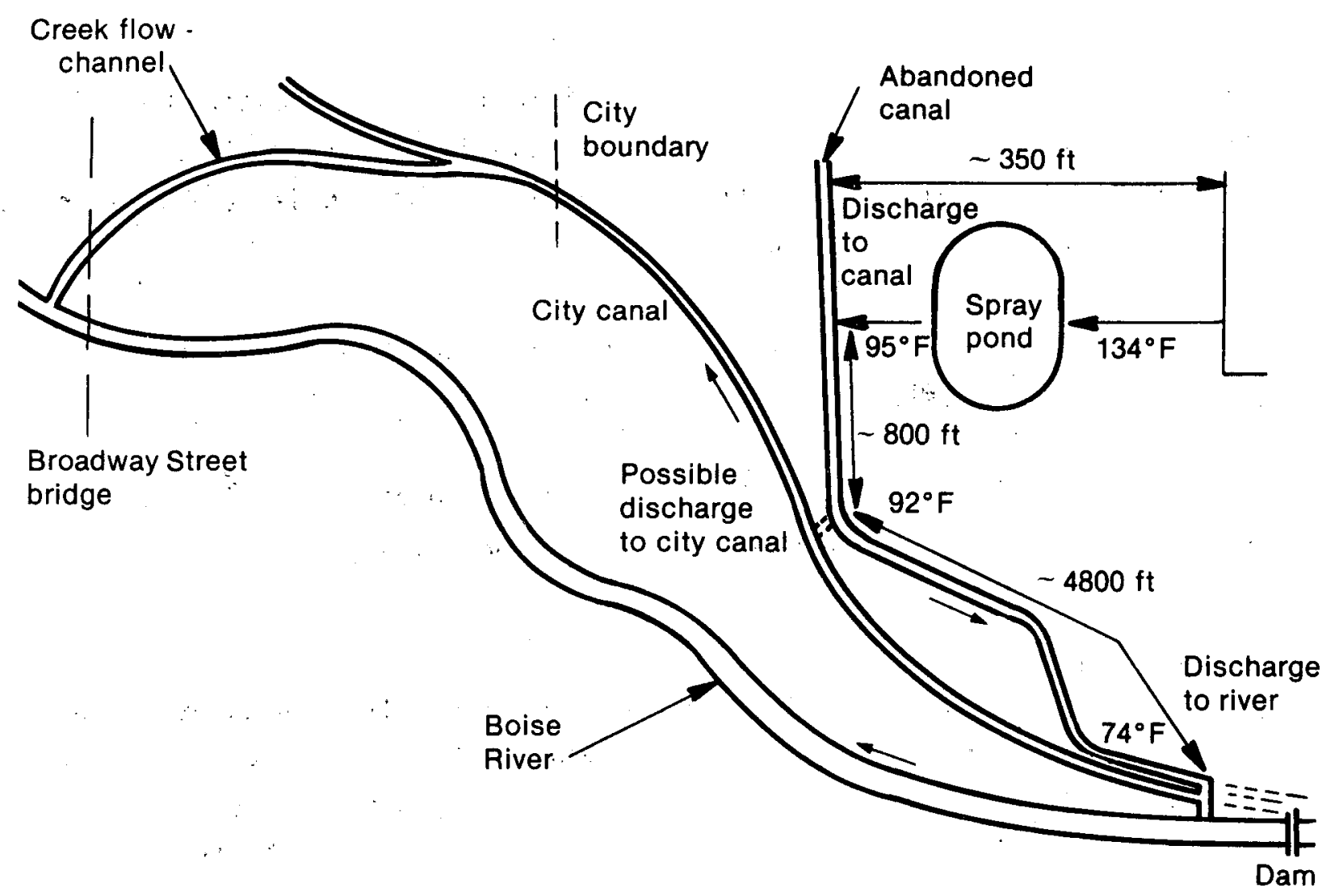

INEL 20285

Figure 1. Geothermal effluent disposal options.

Considering the desirability of obtaining data for similar future geothermal applications and the accessibility of canal systems for both river and irrigation discharge, provision to use either discharge option appeared desirable unless prohibited by environmental considerations. The feasibility of including several optional disposal systems in this conversion for comparison and evaluation purposes also eppeared desirable. 


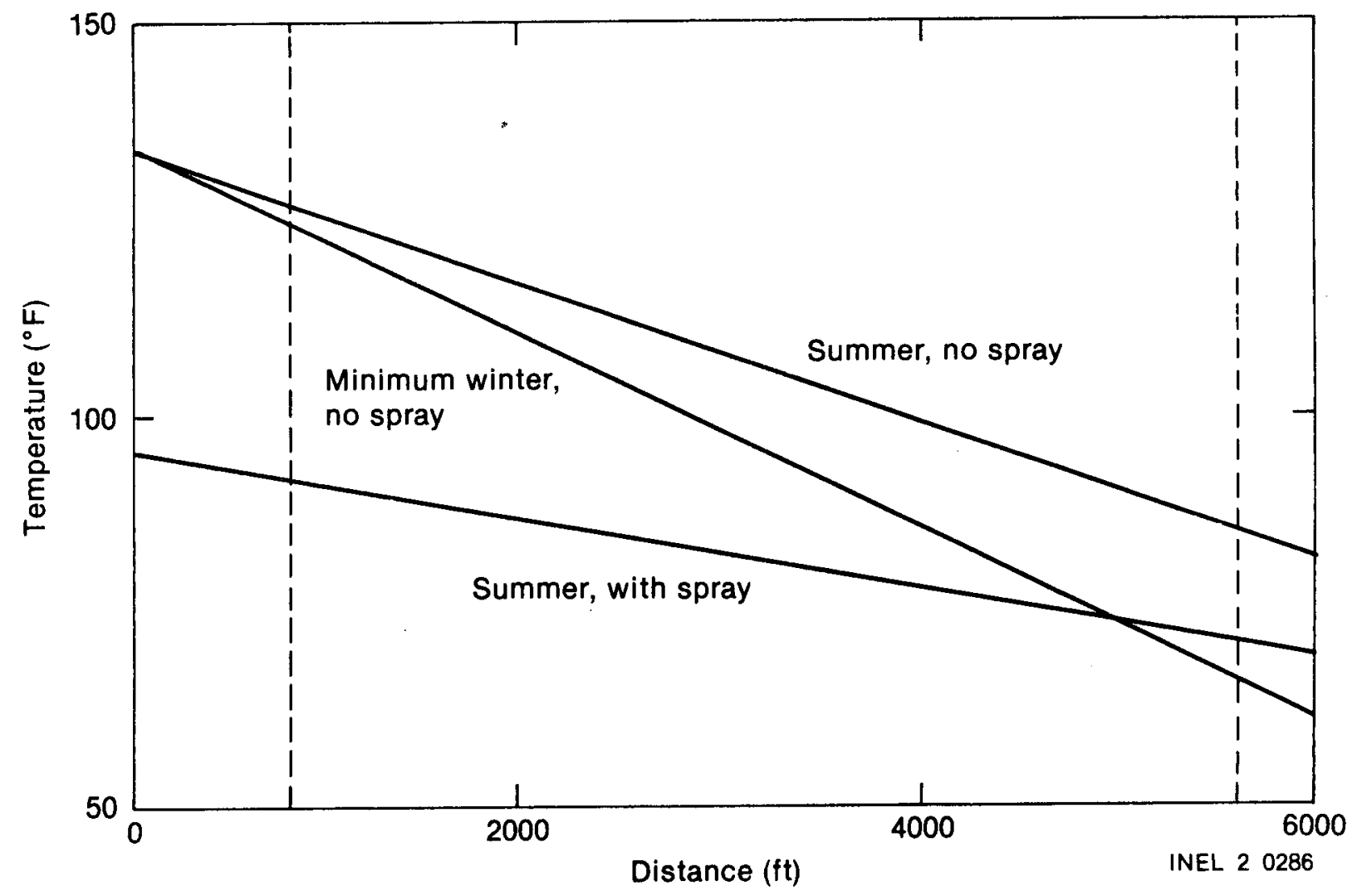

Figure 2. Cooling of effluent over distance with and without spray cooling. 